\title{
Research on the Impact of Sino-US Trade Structure on the Real Effective Exchange Rate of RMB
}

\author{
Jiajia Yan and Jinlong Cai iD \\ School of Economics and Management, Fuzhou University, Fuzhou 350108, China \\ Correspondence should be addressed to Jinlong Cai; n190727092@fzu.edu.cn
}

Received 25 August 2021; Revised 5 October 2021; Accepted 27 October 2021; Published 18 November 2021

Academic Editor: Stefan Cristian Gherghina

Copyright (C) 2021 Jiajia Yan and Jinlong Cai. This is an open access article distributed under the Creative Commons Attribution License, which permits unrestricted use, distribution, and reproduction in any medium, provided the original work is properly cited.

\begin{abstract}
Since the beginning of 2018, Sino-US trade frictions have been escalating to the fields of science and technology, finance, and geography. Especially in the financial field, the United States has forcibly identified China as a "currency manipulator." In order to analyze the impact of Sino-US trade on the RMB exchange rate, based on the Sino-US import and export trade data under the quarterly HS classification from 2003 to 2019 and the RMB real effective exchange rate, this article carries out the traditional time series test, seasonal unit root test, and cointegration test and further constructs the seasonal error correction model to explore the long-term and short-term dynamic impact of Sino-US import and export trade structure on RMB real effective exchange rate. The results shows that the upgrading and optimization of the overall trade structure between China and the United States will increase the appreciation pressure of RMB real effective exchange rate. There are seasonal and long-term trends between RMB real effective exchange rate and different types of import and export trade structures between China and the United States. Therefore, this article not only strongly refutes the "theory of RMB appreciation" and puts forward policy suggestions to effectively deal with the negative impact of Sino-US trade friction but also provides a research framework for global trade, especially the decoupling of trade structure and exchange rate between developing and developed countries.
\end{abstract}

\section{Introduction}

Western media have long attributed the huge Sino-US trade surplus to exchange rate distortions caused by the artificial undervaluation of the RMB. Based on this, the "RMB appreciation theory" believes that RMB appreciation can reduce the scale of the Sino-US trade surplus, which is conducive to achieving a balance of US trade balance (Krugman, Jaime and John, and Won and Renan, respectively [1-3]). Since 2018, the Sino-US trade friction has intensified, and the relationship between the RMB exchange rate and the Sino-US trade balance has once again become the focus of discussion in the public and academic circles, and calls for the appreciation of the RMB continue to rise. However, only paying attention to the impact of the RMB exchange rate on the scale of trade balances will inevitably be biased. To fundamentally solve trade imbalances, we must also pay attention to the issue of trade structure imbalances. Most existing studies have focused on the relationship between total trade volume and the exchange rate. There are few studies on the relationship between trade structure and exchange rate. Few scholars have studied the RMB exchange rate from the perspective of Sino-US trade structure. Therefore, from the perspective of the Sino-US trade structure, this article clarifies the relationship between the Sino-US trade structure and the RMB exchange rate. It has profound theories for distinguishing the Sino-US exchange rate disputes and adjusting the Sino-US trade structure imbalance, and forming a mutually beneficial and win-win trade model is of far-reaching theoretical and practical significance.

\section{Literature Review}

At present, scholars have carried out fewer studies on the impact of trade structure on the RMB exchange rate, and the theoretical basis is the "Balassa-Samuelson" effect. The "Balassa-Samuelson" effect is that two scholars, Balassa and 
Samuelson, explain the trend of real exchange rates from the perspective of relative production efficiency. There are differences in the rate growth rate. When a country's economy grows rapidly, that is, when the production efficiency of the trade sector increases significantly, it is often accompanied by an increase in the real exchange rate and an appreciation of the national currency.

Quan corrected the "Balassa-Samuelson" effect by reviewing the evolution of the trade structure and exchange rate in the course of Japan's modernization. He believed that the upgrading of the export structure was the main reason for the appreciation of the currency. Under the conditions of a substantial appreciation, China should adopt measures to restrict exports on its own to ease trade frictions [4]. Pan and $\mathrm{Xu}$ established a theoretical model of the effect of industrial transfer on real exchange rate changes and conducted empirical tests on the actual situation in Japan since the 1960 s and the actual situation in China since the 1980s. The results confirmed that the "Balassa-Samuelson" effect is established in China; that is, the increase in the real exchange rate brought about by the increase in labor productivity of tradable goods exists in China [5]. Ma and Xu conducted a Granger causality test on China's quarterly data from 1980 to 2003 and found that there is a cointegration relationship between the real effective exchange rate of the $\mathrm{RMB}$ and China's export structure and that China's export structure is a Granger of the RMB exchange rate. Jie's reason can explain the changes in the RMB exchange rate to a certain extent [6]. Wang et al. conducted an empirical study on the relationship between the Sino-US trade structure and the RMB real effective exchange rate based on the annual data of the SinoUS trade structure and the RMB real effective exchange rate from 1980 to 2004. The results showed that China's total trade structure and export trade structure and the RMB real exchange rate are Granger causal to each other, and there is no cointegration relationship between the import trade structure and the RMB real exchange rate [7]. Xie and Liu found that there is an interactive relationship between the RMB real exchange rate and China's import and export trade. Adjusting the structure of China's international trade balance can effectively reduce the imbalance of the RMB real exchange rate and alleviate trade frictions between countries [8]. Marseilles added the trade structure to the purchasing power parity theory, emphasizing that the trade structure is effective on the equilibrium exchange rate through the wage effect and the wealth effect, and it is proved by the establishment of a three-sector economic model and the data of 264 countries from 1995 to 2018. An improvement in the trade structure will indeed lead to an appreciation of the equilibrium exchange rate [9]. Jin established the Redux model and found that the real exchange rate of the RMB can withstand various shocks under the conditions of open trade and maintain stability. With the optimization of the trade structure, the effect of restraining the fluctuation of the real exchange rate of the RMB will become stronger [10]. In addition, the depth and breadth of some scholars' research on trade are increasing. Wang and Han based their research on the decoupling of economic growth and carbon emissions between China and the United States (Wang et al.), by using multiregional input-output (MRIO), Tapio decoupling model, and structural decomposition analysis (SDA) to study the decoupling and driving factors of carbon emissions in Sino-US trade; it is found that the carbon emission decoupling reflected in China's exports to the United States is relatively unchanged and gradually improved, while the carbon emission decoupling reflected in the United States' exports to China is variable $[11,12]$.

Although the above-mentioned scholars' research has provided some reference for exploring the influence of the Sino-US trade structure on the RMB exchange rate, there are still the following shortcomings. First, the existing literature mostly pays attention to the total index data of trade balance and does not fully consider the differences in the trade structure reflected by the heterogeneity of different commodities. Second, most of the time periods covered by existing studies started from the 1990s to 2008 after the outbreak of the global financial crisis and did not cover the time period after the escalation of Sino-US trade frictions, so there is a lack of timeliness. Third, in order to reduce the loss of data information, existing studies mostly use actual data without seasonal adjustments when adopting traditional measurement methods. However, both exchange rate and trade structure data have significant seasonal characteristics, and data that does not eliminate seasonality will inevitably lead to potential relationships between related variables being incorrectly estimated and inferred. Based on this, this article uses the "Balassa-Samuelson" effect as the theoretical basis, using traditional time series testing and seasonal testing to explore the impact of the overall trade structure of China and the United States and the structure of different types of import and export trade between China and the United States on the real effective exchange rate of the RMB. First of all, this article uses the relative ratio of the highproductivity product rates in the import and export trade sectors of China and the United States, that is, the relative ratio of capital-intensive import and export trade under the HS classification standard to express the overall trade structure of China and the United States, and analyzes the overall trade structure of China and the United States, as well as whether it has an impact on the real effective exchange rate of the RMB and whether it conforms to the "BalassaSamuelson" effect. Secondly, according to the HS classification standard, the Sino-US trade products are further classified into the quarterly data of China's capital-intensive, resource-intensive, and labor-intensive export and import trade with the United States. The seasonal cointegration test and seasonal error correction model are used to study the differences between China and the United States, as well as the impact of the structure of import and export trade on the long- and short-term dynamics of the real effective exchange rate of the RMB. Compared with the simple time series error correction model, this model can comprehensively analyze the dynamic evolution mechanism between Sino-US import and export trade structure and RMB real effective exchange rate on the premise of considering the heterogeneity of import and export trade of various products and the possible multiple long-term cointegrations relationship between relevant variables at different frequencies. Finally, based on 
the empirical results of the above two parts, corresponding policy recommendations are put forward for Sino-US trade frictions.

\section{Theoretical Model}

The "Balassa-Samuelson" effect is a hypothesis explaining the relationship between exchange rate changes and productivity. The model mainly assumes complete competition in the commodity market, free flow of domestic factor sectors across sectors, and the establishment of the law of one price for traded goods. The theoretical derivation is as follows: $P, P^{*}$ represent the price levels of the two countries, respectively, and the tradable-goods sector and the nontradable-goods sector are denoted by subscripts $T$ and $N$, respectively. The price level of a country can be obtained by the weighted average of the price of traded goods and the price of nontraded goods. Then the price levels of the two countries can be expressed as equations (1) and (2), respectively, where $\theta$ and $1-\theta$ are the prices of traded goods and the weight of the price of nontradable goods.

$$
\begin{gathered}
P=\left(P_{T}\right)^{\theta}\left(P_{N}\right)^{1-\theta}, \\
P^{*}=\left(P_{T}^{*}\right)^{\theta}\left(P_{N}^{*}\right)^{1-\theta} .
\end{gathered}
$$

Under open conditions, the price of trade products must meet $P_{T}=P_{T}^{*}$, as shown in the following formula:

$$
\frac{P}{P^{*}}=\left(\frac{P_{T}}{P_{T}^{*}}\right)^{\theta}\left(\frac{P_{N}}{P_{N}^{*}}\right)^{1-\theta}=\left(\frac{P_{N}}{P_{N}^{*}}\right)^{1-\theta} .
$$

The logarithm of equation (3) is taken to obtain the following equation:

$$
\begin{aligned}
P-P^{*} & =(1-\theta)\left(P_{N}-P_{N}^{*}\right), \\
Y_{i} & =A_{i} K_{i}^{\alpha_{i}} L_{i}^{1-\alpha_{i}}, \\
\operatorname{LR} & =P_{i}^{*} Y_{i}-w L_{i}-r K_{i} .
\end{aligned}
$$

Assuming that $P_{T}=P_{T}^{*}=1$, the optimal first-order conditions of the traded-goods sector and the nontradedgoods sector are equations (7) and (8), in which the per capita capital $k_{i}=\left(K_{i} / L_{i}\right)$.

$$
\begin{aligned}
A_{T}\left(k_{T}\right)^{\alpha_{T}} & =W+r k_{T}, \\
P_{N} A_{N}\left(k_{N}\right)^{\alpha_{N}} & =W+r k_{N} .
\end{aligned}
$$

The logarithm of equations (7) and (8) is taken to obtain equations (9) and (10), where $U_{L i}$ represents the share of labor income in the production sector.

$$
\begin{aligned}
A_{T} \alpha_{T} & =W U_{L T}, \\
P_{N} A_{N} \alpha_{N} & =W U_{L N} .
\end{aligned}
$$

From formulas (9) and (10), the following formula can be obtained:

$$
P=\frac{U_{L N}}{U_{L T}} \frac{\alpha_{T}}{\alpha_{N}} A_{T}-A_{N} .
$$

Substituting formula (11) into formula (4), we get the following formula:

$$
P-P^{*}=(1-\theta)\left[\frac{U_{L N}}{U_{L T}} \frac{\alpha_{T}}{\alpha_{N}}\left(A_{T}-A_{T}^{*}\right)-\left(A_{N}-A_{N}^{*}\right)\right] .
$$

The labor intensity of the nontradable-product sector is generally higher than that of the tradable-product sector; namely, $\alpha_{N}<\alpha_{T}$; that is, $U_{L N}>U_{L T}$.

Assuming that the production factors of the tradable and nontradable sectors are capital and labor, the production function and profit function with constant returns to scale of the two sectors can be expressed by equations (5) and (6), respectively, where $A_{i}$ represents the total factor productivity of the two sectors; $i=T$ or $N$.

The changes in the productivity of the tradable sector are ultimately reflected in the trade structure. According to the "International Trade Standard Classification," a country's trade products can be divided into capital-intensive, laborintensive, and resource-intensive products. It is generally believed that labor-intensive products have low technical content, and the increase in the proportion of capital-intensive products can represent an increase in the productivity level of the traded goods sector, thereby increasing the real exchange rate level. In a country with rapid economic growth, the proportion of capital-intensive products in its trade structure will inevitably continue to increase, so that the productivity of the country's trade product sector is also constantly improving. Therefore, based on the above analysis of the main conclusions of the "Balassa-Samuelson" effect, we can draw the following conclusions: changes in a country's trade structure will affect changes in a country's real exchange rate.

\section{Samples and Variables}

4.1. Explanatory Variable: Structural Variables of Sino-US Trade. According to the HS classification standard, this article classifies Sino-US trade products into capital-intensive, labor-intensive, and resource-intensive products. Among them, capital-intensive products include categories 16,17 , and 18 in the HS classification standard, labor-intensive products include categories 7, 8, 9, 11, and 12 in the HS classification standard, and resource-intensive products include categories 5, 6, 13, and 15 in the HS classification standard. Capital-intensive imports, labor-intensive imports, and resource-intensive imports are represented by IZBMJ, ILDMJ, and IZYMJ, respectively, and capital-intensive exports, labor-intensive exports, and resource-intensive exports are represented by EZBMJ, ELDMJ, and EZYMJ, respectively.

This article defines capital-intensive products as highproductivity products and labor-intensive and resourceintensive products as low-productivity products. The rate of high-productivity products in China's export trade to USA 
represents China's export structure to the US CTTA; namely, $\quad \mathrm{CTTA}=($ EZBMJ/EZBMJ + ELDMJ + EZYMJ $)$. The rate of high-productivity products in China's import trade with the United States represents the ATTC of China's import structure to the United States; namely, $\mathrm{ATTC}=(\mathrm{IZBMJ} / \mathrm{IZBMJ}+\mathrm{ILDMJ}+\mathrm{IZYMJ})$.

Since the overall Sino-US trade structure (TS) is negatively correlated with the import trade structure and positively correlated with the export trade structure, the overall Sino-US trade structure can be expressed by the ratio of the export trade structure to the import trade structure; namely,

$$
\mathrm{TS}=\frac{\mathrm{CTTA}}{\mathrm{ATTC}}
$$

The quarterly trade data used in this article from 2003 to 2019 are all from the China Economic Network database.

4.2. Explained Variable: Real Effective Exchange Rate of RMB. The real effective exchange rate of $\mathrm{RMB}$ is the real effective exchange rate after adjusting the relative price level between China and the United States. The calculation formula is $\operatorname{REER}=\left(P / E * P^{*}\right)$, where $P$ represents the price level in China, $P^{*}$ represents the price level in the United States, and $E$ represents the nominal exchange rate expressed by the direct price method. The increase in the real effective exchange rate of the RMB means the appreciation of the RMB and an increase in the purchasing power of the RMB.

The quarterly data on the real effective exchange rate of RMB used in this article from 2003 to 2019 come from the IFS database of the International Monetary Fund (IMF).

\section{Results and Discussion}

\subsection{An Empirical Test of the Impact of Sino-US Trade Structure on the Real Effective Exchange Rate of RMB}

5.1.1. Stationarity Test. This article takes the natural logarithm of the variables related to the Sino-US trade structure and the real effective exchange rate of the RMB and then performs the ADF unit root test. The results are shown in Table 1. The first-order difference between the overall SinoUS trade structure, China's import structure to the United States, China's export structure to the United States, and the real effective exchange rate of the RMB is significant at the $5 \%$ level, indicating that they are a stationary series after the first-order difference.

5.1.2. Cointegration Test. The cointegration test results of TS, ATTC, CTTA, and REER (see Table 2) show that, at 5\% significance level, the overall trade structure of China and the United States, the import structure of China to the United States, the export structure of China to the United States, and the real effective exchange rate of $\mathrm{RMB}$ are cointegrated. It can be seen from equation (14) that the coefficient of the overall trade structure variable between China and the United States is positive, indicating that the upgrading of the overall trade structure between China and the United States has a positive effect on the real effective
TABLE 1: Stationarity test.

\begin{tabular}{lccc}
\hline Variables & Test equation form & ADF & Conclusion \\
\hline DINREER & $(C, T, 0)$ & $-10.1^{* * *}$ & Yes \\
DINTS & $(C, T, 2)$ & $-12.1^{* * *}$ & Yes \\
DATTC & $(C, T, 1)$ & $-12.5^{* * *}$ & Yes \\
DCTTA & $(C, T, 4)$ & $-10.9^{* * *}$ & Yes \\
\hline
\end{tabular}

Note. The form of the test equation is $(C, T, L)$, where $C, T$, and $L$ represent the constant term, the trend term, and the lag order, respectively; the selection of the optimal lag order is based on the AIC and SC criteria. $T$ statistics are in parentheses. ${ }^{*} p<0.10,{ }^{* *} p<0.05$, and ${ }^{* * *} p<0.01$.

exchange rate of the RMB; that is, the upgrading of the overall trade structure between China and the United States will promote the appreciation of the RMB. This result is consistent with the description of the "Balassa-Samuelson" effect. For every 1 percentage point improvement in the overall trade structure of the US and China, the real effective exchange rate of the RMB rose by 6.14 percentage points. According to formula (15), for every 1 percentage point improvement in the structure of China's import trade with the United States, the real effective exchange rate of the RMB drops by 4.64 percentage points. According to formula (16), for every 1 percentage point improvement in the structure of China's export trade with the United States, the real effective exchange rate of the RMB drops by 15.2 percentage points. The results of formulas (15) and (16) show that the structure of China's import trade with the United States and the structure of its export trade only partly reflect the changes in productivity in the tradable sector and indirectly affect the real effective exchange rate of the RMB (Wang et al. [7]); the assumptions that embody the Balassa-Samuelson effect do not match China's reality (Yang, $\mathrm{Hu}$, and Zeng, $\mathrm{Lu}$ and Liu, Lin, and $\mathrm{Bu}$, respectively [13-17]). The "Balassa-Samuelson" effect requires the free flow of capital and at the same time requires the product market to be a perfectly competitive market. However, in fact, due to the distortion of the market system and capital control in China, the "Balassa-Samuelson" effect may be possibly suppressed or amplified.

$$
\begin{aligned}
& \text { INREER }=\begin{array}{cc}
6.142 \mathrm{INTS}-4.658 \\
(1.149) & (0.089)
\end{array}, \\
& \text { INREER }=\begin{array}{c}
-4.636 \mathrm{INATTC}-6.900 \\
(1.011)
\end{array}, \\
& \text { INREER }=\begin{array}{l}
-15.15 \mathrm{INCTTA}-12.08 \\
(1.446)
\end{array},
\end{aligned}
$$

5.1.3. Robustness Test. This article replaces the Sino-US trade structure (TS) classified according to the HS classification standard in the original model with the Sino-US trade structure (RTS) classified according to the SITC standard, that is, the ratio of China's export structure to the United States and China's import structure to the United States. China's export structure to the United States and the import structure, respectively, represent the proportion of manufactured goods in China's import trade and export trade with 
TABLE 2: Cointegration test results.

\begin{tabular}{lcccc}
\hline Variables & Trace statistics & $p$ value & $5 \%$ level & Number of cointegration equations \\
\hline \multirow{2}{*}{ (INREER, INTS) } & 28.19 & 0.003 & 20.26 & None \\
& 2.723 & 0.633 & 9.164 & At most one \\
\multirow{2}{*}{ (INREER, INATTC) } & 21.66 & 0.040 & 20.26 & None \\
\multirow{2}{*}{ (INREER, INCTTA) } & 2.957 & 0.588 & 9.164 & At most one \\
& 86.92 & 0.001 & 20.26 & None \\
\hline
\end{tabular}

the United States. The last five categories of the Standard International Trade Classification (SITC) are industrial finished products, followed by chemical (finished) products and related products, as well as finished products classified by raw materials (mainly related to textile products, rubber products, mining and metallurgical products, and related products), machinery and transportation equipment, miscellaneous products, and unclassified (other) commodities. The empirical results after the replacement of the data classification standard are shown in equation (17). The $t$ value is greater than 1.96 , indicating that the replacement variable is significant at the $5 \%$ level and the coefficient sign is positive, which is consistent with the original model test result, so the model passed the robustness test.

$$
\text { INREER }=\begin{aligned}
& 0.748 \mathrm{INRTS}+4.368 \\
& (0.086) \quad(0.033)
\end{aligned} .
$$

\subsection{An Empirical Test of the Impact of Different Types of Import} and Export Trade Structures between China and USA on the Real Effective Exchange Rate of RMB. Since the traditional time series analysis method cannot fully mine and make use of the rich information contained in the time dimension of high-frequency trade data, the potential multiple cointegrations relationship between RMB exchange rate and trade structure at different frequencies is ignored. Therefore, this article uses seasonal test to make a comprehensive dynamic analysis of Sino-US trade structure on RMB real effective exchange rate from a higher heterogeneous classification level. Based on the HS classification standard, Sino-US trade products are further divided into quarterly data of China's capital-intensive, resource-intensive, and labor-intensive exports and imports to the United States. On this basis, the seasonal unit root test, seasonal cointegration test, and seasonal error correction model are used to study the longterm and short-term dynamic effects of different types of import and export trade structures between China and the United States on the real effective exchange rate of RMB. For the specific empirical process, we refer the reader to the works of Hylleberg et al., Joseph and Miron, and Su and Lu, respectively [18-20].

5.2.1. HEGY Seasonal Unit Root Test. It can be seen from Figure 1 that the import and export trade of different types of products between China and the United States has obvious seasonal characteristics, so this article uses the HEGY seasonal unit root test.
The idea of HEGY test is to realize the simultaneous test of the unit root of 0 frequency and seasonal frequency by factoring the seasonal difference operator $\left(1-L^{s}\right)$ on different seasonal frequencies. When using seasonal data, the method of seasonal difference should be used to make the series stable. The difference equation is $y_{t}-y_{t-4}=$ $\left(1-L^{4}\right) y_{t},\left(1-L^{4}\right)$ is a seasonal operator. This article constructs the regression equation of the HEGY seasonal unit root test as follows:

$$
\left(1-L^{4}\right) y_{t}=\mu_{t}+\pi_{1} y_{1, t-1}+\pi_{2} y_{2, t-1}+\pi_{3} y_{3, t-2}+\pi_{4} y_{3, t-1}+\varepsilon_{t} .
$$

Here, $\mu_{t}$ is composed of constant items, seasonal dummy variables, and trend items; $\pi_{i}(i=1,2,3,4)$ is the regression coefficient; $\varepsilon_{t}$ is white noise; $y_{t}$ contains 4 unit roots; that is, at 0 frequency, the unit root is +1 ; at $1 / 2$ frequency, the unit root is -1 ; at $1 / 4$ frequency, the unit root is $\pm i$. $\left(1-L^{4}\right)=(1-L)(1+L)\left(1+L^{2}\right), \quad y_{1, t}=\left(1+L+L^{2}+L^{3}\right)$ $y_{t}, y_{2, t}=-\left(1-L+L^{2}-L^{3}\right) y_{t}$, and $y_{3, t}=-\left(1-L^{2}\right) y_{t}$. The test includes 3 null hypotheses: $\pi_{1}=0, \pi_{2}=0, \pi_{3}=\pi_{4}=0$. $\pi_{1}, \pi_{2}$ is the $t$-test statistic; $\pi_{3}, \pi_{4}$ is the $F$ joint test statistic. The test critical value refers to the research results of Hylleberg et al. [18], which are used to test unit roots with frequencies of $0,1 / 2$, and $1 / 4$, respectively. The results of the seasonal unit root test of China's import and export trade structure of capital-intensive, labor-intensive, and resourceintensive products of the United States and the real effective exchange rate of RMB are shown in Table 3.

\subsubsection{Seasonal Cointegration Test and Long-Term Impact} Test. Since all variables contain seasonal unit roots, it is shown that there may be a cointegration relationship between the China-USA import and export trade structure and the real effective exchange rate of RMB at frequencies of $0,1 / 2$, and $1 / 4$. The EG two-step method is used to perform the following cointegration test on the three frequencies of $0,1 / 2$, and $1 / 4$.

At frequencies of $0,1 / 2$, and $1 / 4$, the cointegration test regressions of China's capital-intensive, labor-intensive, and resource-intensive import and export trade structure against the real effective exchange rate of the RMB to the United States are, respectively, shown in the two following equations:

$$
\begin{aligned}
& \operatorname{INREER}_{i t}=\alpha_{i t} I_{i t}+\varepsilon_{i t-I}, \\
& \text { INREER }_{e t}=\beta_{e t} E_{e t}+\varepsilon_{e t-E} .
\end{aligned}
$$




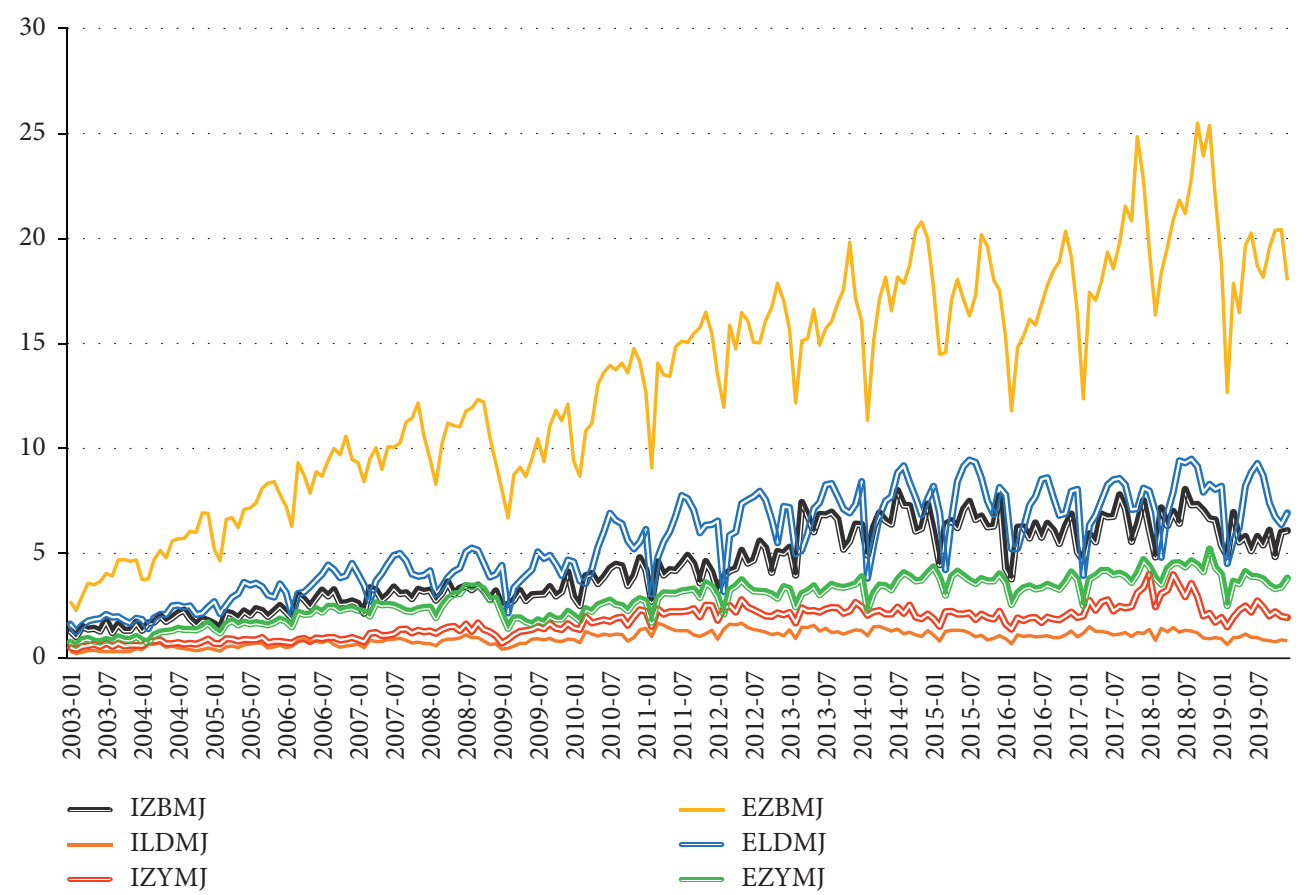

FIgURE 1: Seasonal characteristics of import and export trade of different types of products between China and the United States.

TABLE 3: HEGY test results.

\begin{tabular}{|c|c|c|c|c|c|c|c|}
\hline & INIZBMJ & INEZBMJ & INILDMJ & INELDMJ & INIZYMJ & INEZYMJ & INREER \\
\hline$t_{\pi 1}$ & 1.121 & -0.109 & -0.460 & -0.003 & -1.523 & 0.040 & -1.329 \\
\hline Conclusion & Yes & Yes & Yes & Yes & Yes & Yes & Yes \\
\hline$t_{\pi 2}$ & -0.509 & 1.605 & 0.339 & 0.388 & 1.935 & 1.161 & 1.518 \\
\hline Conclusion & Yes & Yes & Yes & Yes & Yes & Yes & Yes \\
\hline$F_{2(\pi 3, \pi 4)}$ & 1.618 & 1.234 & 0.323 & 2.086 & 0.425 & 0.261 & 1.421 \\
\hline Conclusion & Yes & Yes & Yes & Yes & Yes & Yes & Yes \\
\hline
\end{tabular}

Here, $i, e=1,2,3$ correspond to the data of 0 frequency, $1 / 2$ frequency, and 1/4 frequency of the inlet and outlet, respectively; $Y_{1 t}=\left(1+L+L^{2}+L^{3}\right) Y_{t}, I_{1 t}=\left(1+L+L^{2}+\right.$ $\left.L^{3}\right) I_{t}, E_{1 t}=\left(1+L+L^{2}+L^{3}\right) E_{t} ; Y_{2 t}=-\left(1-L+L^{2}-L^{3}\right) Y_{t}$, $I_{2 t}=-\left(1-L+L^{2}-L^{3}\right) I_{t}, \quad E_{2 t}=-\left(1-L+L^{2}-L^{3}\right) \quad E_{t}$; $Y_{3 t}=-\left(1-L^{2}\right) Y_{t}, I_{3 t}=-\left(1-L^{2}\right) I_{t}, E_{3 t}=-\left(1-L^{2}\right) E_{t}$; $Y=$ INREER, $I=$ INIZBM, INILDMJ, INIZYMJ , $E=$ INEZBMJ, INELDMJ, INEZYMJ. If the residuals of the above equations $\varepsilon_{i t-I}, \varepsilon_{e t-E}$ are all stable, then the above equation is the cointegration equation of RMB real effective exchange rate and China's capital intensive, labor-intensive, and resource intensive import and export trade structure to the United States at the frequency of $0,1 / 2$, and $1 / 4$, respectively.

The test results of the cointegration relationship between the real effective exchange rate of $\mathrm{RMB}$ and the capitalintensive, labor-intensive, and resource-intensive import and export trade structure of China to the United States at 0 , $1 / 2$, and $1 / 4$ frequencies are shown in Table 4 . At frequencies of $0,1 / 2$, and $1 / 4$, the residuals of the cointegration regression between the real effective exchange rate of RMB and the capital-intensive, labor-intensive, and resource-intensive import and export trade structures are all stable; that is, equations (19) and (20) are the cointegration equations between the real effective exchange rate of $\mathrm{RMB}$ and the structure of China's import and export trade of capitalintensive, labor-intensive, and resource-intensive products with the United States. China's capital-intensive, labor-intensive, and resource-intensive import and export trade structure with the United States has a long-term cointegration relationship with the real effective exchange rate of $\mathrm{RMB}$ at $0,1 / 2$, and $1 / 4$ frequencies, that is, capital at seasonal and nonseasonal frequencies. There is a long-term equilibrium relationship between the import and export trade structure of capital-intensive, labor-intensive, and resourceintensive products and the real effective exchange rate of $\mathrm{RMB}$. At the frequencies of $0,1 / 2$, and $1 / 4$, the capital-intensive, labor-intensive, and resource-intensive import and export trade structures are the long-term influencing factors of the real effective exchange rate of the RMB.

5.2.3. Seasonal Error Correction Model and Short-Term Impact Relationship Test. This article further analyzes the short-term causal relationship between the import and export trade structure of different types of products of China 
TABLE 4: Tests on the $0,1 / 2$, and $1 / 4$ frequency cointegration.

\begin{tabular}{|c|c|c|c|c|c|c|c|}
\hline \multirow{3}{*}{0} & \multirow{3}{*}{$t$ value } & \multicolumn{2}{|c|}{ ZBMJ } & \multicolumn{2}{|c|}{ LDMJ } & \multicolumn{2}{|c|}{ ZYMJ } \\
\hline & & $\begin{array}{c}\mathcal{E}_{1 t-\mathrm{INIZBMJ}} \\
-2.380^{*}\end{array}$ & $\begin{array}{c}\varepsilon_{1 t-\text { INEZBMJ }} \\
-2.722^{*}\end{array}$ & $\begin{array}{c}\varepsilon_{1 t-\text { INILDMJ }} \\
-1.932^{*}\end{array}$ & $\begin{array}{c}\varepsilon_{1 t-\text { INELDMJ }} \\
-2.050^{* *}\end{array}$ & $\begin{array}{l}\varepsilon_{1 t-\mathrm{INIZYMJ}} \\
-2.578^{* * *}\end{array}$ & $\begin{array}{c}\varepsilon_{1 t-\mathrm{INEZYMJ}} \\
-2.748^{* * *}\end{array}$ \\
\hline & & Yes & Yes & Yes & Yes & Yes & Yes \\
\hline \multirow[t]{2}{*}{$1 / 2$} & \multirow[t]{2}{*}{$t$ value } & $\begin{array}{c}\varepsilon_{2 t-\mathrm{INIZBMJ}} \\
-3.833^{*}\end{array}$ & $\begin{array}{c}\varepsilon_{2 t-\mathrm{INEZBMJ}} \\
-3.053^{* *}\end{array}$ & $\begin{array}{c}\varepsilon_{2 t-\text { INILDMJ }} \\
-2.868^{* *}\end{array}$ & $\begin{array}{l}\varepsilon_{2 t-\mathrm{INELDMJ}} \\
-3.498^{* * *}\end{array}$ & $\begin{array}{c}\varepsilon_{2 t-I N I Z Y M J} \\
-2.390^{* *}\end{array}$ & $\begin{array}{c}\varepsilon_{2 t-\text { INEZYMJ }} \\
-3.543^{*}\end{array}$ \\
\hline & & Yes & Yes & Yes & Yes & Yes & Yes \\
\hline \multirow[t]{2}{*}{$1 / 4$} & \multirow[t]{2}{*}{$t$ value } & $\begin{array}{c}\varepsilon_{3 t-\text { INIZBMJ }} \\
-3.432^{* *}\end{array}$ & $\begin{array}{c}\mathcal{E}_{3 t-\mathrm{INEZBMJ}} \\
-2.634^{*}\end{array}$ & $\begin{array}{c}\mathcal{E}_{3 t-\mathrm{INILDMJ}} \\
-4.748^{*}\end{array}$ & $\begin{array}{c}\varepsilon_{3 t-\text { INELDMJ }} \\
-3.748^{* *}\end{array}$ & $\begin{array}{c}\mathcal{E}_{3 t-\mathrm{INIZYMJ}} \\
-2.563^{* *}\end{array}$ & $\begin{array}{c}\varepsilon_{3 t-\mathrm{INEZYMJ}} \\
-3.256^{*}\end{array}$ \\
\hline & & Yes & Yes & Yes & Yes & Yes & Yes \\
\hline
\end{tabular}

Note. The critical values of the seasonal cointegration test for all import and export trade structures determined in this article are as follows: the critical value of $1 \%$ is -2.605 , the critical value of $5 \%$ is -1.946 , and the critical value of $10 \%$ is -1.613 ; ${ }^{* * *}$ rejecting the nonstationary hypothesis at the $1 \%$ significance level, ${ }^{* *}$ rejecting the nonstationary hypothesis at the $5 \%$ significance level, and ${ }^{*}$ rejecting the nonstationary hypothesis at the $10 \%$ significance level.

TABLE 5: Seasonal error correction model.

\begin{tabular}{|c|c|c|c|c|c|c|}
\hline \multirow{2}{*}{ Variable } & \multicolumn{2}{|c|}{ ZBMJ } & \multicolumn{2}{|c|}{ LDMJ } & \multicolumn{2}{|c|}{ ZYMJ } \\
\hline & $\Delta_{4} \mathrm{INREER}_{i t}$ & $\Delta_{4} \mathrm{INREER}_{e t}$ & $\Delta_{4} \mathrm{INREER}_{i t}$ & $\Delta_{4}$ INREER $_{e t}$ & $\Delta_{4} \mathrm{INREER}_{i t}$ & $\Delta_{4} \mathrm{INREER}_{e t}$ \\
\hline$\Delta_{4} \mathrm{INIZBMJ}_{i t}$ & $0.040^{*}$ & & & & & \\
\hline$\Delta_{4} \mathrm{INEZBMJ}_{i t}$ & & $0.030^{*}$ & & & & \\
\hline$\Delta_{4}$ INILDMJ $_{i t}$ & & & $0.041^{* *}$ & & & \\
\hline$\Delta_{4}$ INELDMJ $_{i t}$ & & & & $0.047^{*}$ & & \\
\hline$\Delta_{4}$ INIZYMJ $_{i t}$ & & & & & $0.044^{* *}$ & \\
\hline$\Delta_{4} \mathrm{INEZYMJ}_{i t}$ & & & & & & $0.050^{* * *}$ \\
\hline $\mathrm{ECM}_{0}$ & $-0.060^{*}$ & $-0.013^{*}$ & $-0.066^{* *}$ & $-0.074^{*}$ & $-0.088^{* *}$ & $-0.050^{*}$ \\
\hline $\mathrm{ECM}_{1 / 2}$ & $-0.090^{*}$ & $-0.091^{*}$ & $-0.039^{*}$ & $-0.007^{*}$ & $-0.047^{*}$ & $-0.018^{*}$ \\
\hline $\mathrm{ECM}_{1 / 4}$ & $-0.140^{* *}$ & $-0.458^{* *}$ & $-0.147^{* *}$ & $-0.230^{* *}$ & $-0.701^{* * *}$ & $-0.594^{* * *}$ \\
\hline
\end{tabular}

Note. The model is shown. $T$ statistics are in parentheses. ${ }^{*} p<0.10,{ }^{* *} p<0.05$, and ${ }^{* * * *} p<0.01$.

and the United States and the real effective exchange rate of the RMB by constructing a seasonal error correction model, as well as the adjustment strength of the short-term deviation of related variables to the long-term equilibrium, and constructs a model as shown in the two following equations:

$$
\begin{aligned}
\Delta_{4} \mathrm{INREER}_{i t}= & C_{i}+\Delta_{4} \mathrm{INI}_{t}+\lambda_{1} \mathrm{ECM}_{i, 0}+\lambda_{2} \mathrm{ECM}_{i,(1 / 2)} \\
& +\lambda_{3} \mathrm{ECM}_{i,(1 / 4)}
\end{aligned}
$$

$$
\begin{aligned}
\Delta_{4} \mathrm{INREER}_{e t}= & D_{i}+\Delta_{4} \mathrm{INE}_{t}+\eta_{1} \mathrm{ECM}_{e, 0}+\eta_{2} \mathrm{ECM}_{e,(1 / 2)} \\
& +\eta_{3} \mathrm{ECM}_{e,(1 / 4)} .
\end{aligned}
$$

Here, $\quad I=$ INIZBMJ, INILDMJ, INIZYMJ; $E=$ INEZBMJ, INELDMJ, INEZYMJ; error correction terms $\left(\mathrm{ECM}_{i, 0}, \mathrm{ECM}_{i,(1 / 2)}, \mathrm{ECM}_{i,(1 / 4)}\right)$, respectively, represent the residuals of the cointegration relationship between the real effective exchange rate of RMB and China's capitalintensive, labor-intensive, and resource-intensive import trade structure with the United States at $0,1 / 2$, and 1/4 frequencies. In the same way, $\mathrm{ECM}_{e, 0}, \mathrm{ECM}_{e,(1 / 2)}, \mathrm{ECM}_{e,(1 / 4)}$, respectively, represent the residuals of the cointegration relationship between the real effective exchange rate of RMB and China's capital-intensive, labor-intensive, and resourceintensive export trade structure to the United States at $0,1 / 2$, and $1 / 4$ frequencies. If the original hypothesis $\left(\eta_{i}=0(i=1,2,3)\right)$ does not hold, it means that there is an error correction mechanism at $0,1 / 2$, and $1 / 4$ frequencies, and vice versa. The lag period selected in this article is 1 , and the results of the seasonal error correction are given in Table 5.

In the short term, China's capital-intensive, labor-intensive, and resource-intensive import and export trade structure with the United States is a short-term influencing factor of the real effective exchange rate of the RMB. The resulting appreciation pressure further verified the existence of the "Balassa-Samuelson" effect. In addition, the error correction models of capital-intensive, labor-intensive, and resource-intensive import and export trade structures at the frequencies of $0,1 / 2$, and $1 / 4$ are negative numbers and all have passed the $10 \%$ significance test. There is a long-term equilibrium relationship between the import and export trade structure of similar products and the real effective exchange rate of RMB in both nonseasonal frequency and seasonal frequency. Different types of trade structures in nonseasonal frequency and seasonal frequency will have an impact on the real effective exchange rate of RMB. At the same time, the coefficient of the error correction term reflects the adjustment strength that deviates from the longterm equilibrium. The adjustment coefficient of the error correction term at $1 / 4$ frequency is generally greater than the adjustment coefficient at 0 frequency and $1 / 2$ frequency, indicating that capital-intensive, labor-intensive, and resource-intensive short-term changes have significantly greater adjustment strength for deviations from $1 / 4$ frequency balance than deviations from 0 frequency and $1 / 2$ 
frequency. As far as the Sino-US capital-intensive import trade structure is concerned, at 0 frequency, when shortterm fluctuations deviate from the long-term equilibrium, the $6.03 \%$ deviation of the RMB's real effective exchange rate from the long-term equilibrium will be adjusted. At the frequency of $1 / 2$, the deviation of the real effective exchange rate of RMB from $9.02 \%$ of the long-term equilibrium will be adjusted. At the frequency of $1 / 4$, the deviation of the real effective exchange rate of RMB from the long-term equilibrium of $14.08 \%$ will be adjusted.

\section{Conclusions}

First of all, based on the "Balassa-Samuelson" effect, this article uses the cointegration method to test the impact of the overall trade structure of China and the United States on the real effective exchange rate of the RMB and finds that the overall trade structure between China and the United States has a positive correlation with the real effective exchange rate of the RMB. That is to say, the upgrading and optimization of the overall trade structure between China and the United States will increase the pressure on the appreciation of the real effective exchange rate of the RMB. Secondly, seasonal cointegration test is performed and seasonal error correction model is constructed to further verify the mechanism of Sino-US capital-intensive, labor-intensive, and resourceintensive import and export trade structure on the real effective exchange rate of RMB. In terms of seasonal frequency, there are seasonal and long-term trends between the real effective exchange rate of RMB and different types of Sino-US import and export trade structures. The different types of Sino-US import and export trade structures are both the RMB real effective exchange rate at the long-term and short-term cyclical levels, factors affecting changes.

Different from the traditional research methods, the seasonal test model used in this article improves the effectiveness of the test from the spatial dimension and can accurately describe the fluctuation characteristics of Sino-US trade structure data in different frequencies from the time dimension, as well as the data generation characteristics of RMB real effective exchange rate; it is of great practical significance to formulate corresponding foreign economic development policies. Based on this, it can be considered that the theoretical model and empirical model of this article have confirmed the effectiveness of the conclusion, and the theory can become a tool to analyze the trend of RMB exchange rate, help government departments better predict the trend of exchange rate, and formulate more reasonable control policies on this basis, which has strong practical significance.

As China accelerates the construction of a new development pattern with the domestic big cycle as the main body and the domestic and international double cycles promoting each other, in order to effectively refute the "RMB appreciation theory" and effectively respond to the negative impact of Sino-US trade frictions, this article puts forward the following policy recommendations combined with the empirical results:
First, deepen the reform of the RMB exchange rate formation mechanism, and continue to maintain the two-way expectations and two-way flexibility of the $\mathrm{RMB}$ exchange rate. In the short term, although countercyclical factor adjustment can be used as a policy tool to stabilize exchange rate fluctuations and moderate market sentiment, using this tool too frequently will send negative signals to the market, leading to intensified expectations of RMB depreciation in the offshore market. Only by taking into account the flexibility and stability of the RMB exchange rate formation mechanism can the continuous deterioration of the Sino-US trade imbalance and the risk and pressure of the formation of the RMB exchange rate "overshoot" be avoided, and the RMB can be effectively hedged against Sino-US trade frictions and the strengthening of the US dollar index. The procyclical sentiment in the direction of devaluation prevents the rapid rise and fall of the RMB exchange rate from amplifying the impact of cyclical fluctuations in the import and export trade structure on trade, so as to better play the role of exchange rate adjustment macroeconomics and automatic balance of payments stabilizer.

Second, promote the upgrading of trade structure and develop new drivers of diversification and high-quality development of foreign trade. On the one hand, lowproductivity sectors such as agricultural products have always been the focus of Sino-US trade frictions. Strengthen trade protection and production support for low-productivity sectors such as agriculture, focus on the expansion of import strategies, increase imports of low-productivity products, and properly handle the expansion of imports. The relationship between ensuring the safety of domestic industries and steadily advancing the construction of a strategic guarantee system for Chinese agricultural products under open conditions will help offset the devaluation pressure of the RMB exchange rate caused by the Sino-US trade friction. On the other hand, increase resource input and policy tilt in high-productivity sectors, achieve rapid breakthroughs in core technologies and key industries, promote the upgrading of trade structure with "brand strategy," cultivate international competitive advantages that extend to mid-to-high-end, and encourage Chinese companies going out, with the help of policy initiatives, such as the "One Belt, One Road" initiative, to broaden the foreign trade corridors for Chinese enterprises.

Third, prevent "false exports" brought about by export encouragement policies, and build a healthy and orderly export rule and market environment. Compared with investment channels and nontrade channels, foreign exchange barriers and risks under trade are small, and they have become the main channel for hot money to flow into China. "False exports" may not only cause the trade balance between China and the United States to be inflated but also put pressure on 
the appreciation of the RMB. If the "export inflated" is dominated by capital-intensive products, it may produce a phenomenon of "false upgrades" in the trade structure; if the "export inflated" is dominated by labor-intensive and resource-intensive products, it may lead to an increase in the price level of such domestic products, which is unfavorable to the longterm development of export enterprises and the upgrading of the trade structure. Therefore, only by strengthening the identification and management of hot money inflows from import and export trade channels between China and the United States, strengthening the functions of import and export administrative agencies, and carefully formulating preferential import and export policies can the normal order of the development of the export-oriented industrialization be ensured, creating a fair international trade competition environment for export enterprises.

Fourth, realize the diversification of trade countries, strive to solve the development dilemma of Sino-US bilateral trade, actively participate in the negotiation and construction of regional economic integration, and establish good bilateral, plurilateral, and multilateral trade relations. We should continue to deepen the construction of "One Belt, One Road" and "Regional Comprehensive Economic Partnership" (RCEP), integrate into regional economic integration organizations, and give full play to the advantages of participating in regional economic integration, so as to promote the diversified development of China's foreign trade and serve China. Participate in the empowerment of international economic and trade cooperation in the future. At the same time, seize the opportunity to promote the negotiation of the China-Japan-Korea Free Trade Area Agreement, as well as in-depth discussion and analysis of the "Comprehensive and Progressive Agreement on Trans-Pacific Partnership" (CPTPP) trade rules, and conduct a systematic study on the possibility of China joining the agreement. Use this as a guarantee to offset US trade unilateralism and expand China's opening up.

Fifth, maintain the strategic determination of currency and trade policies, and work to resolve Sino-US trade frictions. The excessive import caused by the low cost of the US dollar will inevitably lead to successive years of trade deficits between the United States and China. At a time of extreme market volatility and lack of exposure to risks, the Chinese government should maintain the strategic focus of monetary policy, stabilize RMB exchange rate expectations, and increase foreign confidence in RMB assets in order to change the dollardominated world monetary pattern and fundamentally change the state of global trade imbalances. At the same time, trade policies must also maintain strategic determination. Under the premise of maintaining the balance of import and export trade, increase the competitive value and added value of exports and actively expand imports.

\section{Data Availability}

The processed data required to reproduce the findings of this paper cannot be shared at this time as the data also form part of an ongoing study.

\section{Conflicts of Interest}

The authors declare no conflicts of interest.

\section{Authors' Contributions}

J. Y. and J. C. were involved in conceptualization, methodology, validation, formal analysis, and reviewing and editing. J. C. provided software and resources and carried out data curation and original draft preparation. J. Y. was responsible for investigation, visualization, supervision, project administration, and funding acquisition. Both authors have read and agreed to the published version of the manuscript.

\section{Acknowledgments}

This research was funded by National Social Science Foundation Projects (Grant no. 20BJY234).

\section{References}

[1] Krugman, The Instability of Exchange Rate, Peking University Press, Beijing, China, 2000.

[2] M. Jaime and S. John, "Exchange-rate effects on China's trade," Review of International Economics, vol. 15, no. 5, 2007.

[3] W. W. Koo and R. Zhuang, "The role of exchange rate in sinoU.S. bilateral trade," Contemporary Economic Policy, vol. 25, no. 3, pp. 362-373, 2007.

[4] W. Quan, "Trade structure and exchange rate-looking at the balassa-samuelson hypothesis from the comparison of China and Japan," World Economic Research, vol. 11, pp. 42-48, 2003.

[5] Q. Pan and K. Xu, "On the impact of industry transfer on the RMB exchange rate and the adjustment of my country's trade structure-and on my country's neutral trade strategy," Financial and Trade Economics, vol. 9, pp. 24-96, 2005.

[6] D. Ma and $\mathrm{S} . \mathrm{Xu}$, "China's trade revenue and expenditure, trade structure and the real effective exchange rate of RMB," Quantitative Economics and Technical Economics Research, vol. 6, pp. 23-42, 2005.

[7] R. Wang, C. Yu, and J. Wang, "Trade structure of China and real effective exchange rate of RMB," Guangdong social sciences, vol. 3, pp. 39-45, 2008.

[8] F. Xie and T. Liu, "RMB exchange rate misalignment and the two-way effect of import and export trade," Reform, vol. 3, pp. 128-138, 2019.

[9] Marseilles, "The impact of trade structure on equilibrium exchange rate," Financial Theory and Practice, vol. 6, pp. 28-35, 2020.

[10] C. Jin, "Whether trade liberalization reduces the fluctuation of the real effective exchange rate of RMB - an empirical study based on provincial trade and price level data," Research in International Finance, vol. 12, pp. 73-83, 2020.

[11] Q. Wang and X. Han, "Is decoupling embodied carbon emissions from economic output in Sino-US trade possible?" 
Technological Forecasting and Social Change, vol. 169, Article ID 120805, 2021.

[12] Q. Wang, M. Zhao, R. Li, and M. Su, "Decomposition and decoupling analysis of carbon emissions from economic growth: a comparative study of China and the United States," Journal of Cleaner Production, vol. 197, pp. 178-184, 2018.

[13] C.-J. Yang, Study on the Long-Term Adjustment Trend of RMB Real Exchange Rate, Shanghai University of Finance and Economics, Shanghai, China, 2002.

[14] Y. Hu and C. Zeng, "The realistic choice and regulation of China's exchange rate system," Financial Research, vol. 12, pp. 59-74, 2004.

[15] F. Lu and L. Liu, "Labor productivity growth in my country's two sectors and international comparison (1978 2005)-rethinking the relationship between the balassa-samuelson effect and the real exchange rate of RMB," Economics, vol. 6, no. 2, pp. 357-380, 2007.

[16] Y. Lin, "Thoughts and policy recommendations on the RMB exchange rate," The World Economy, vol. 3, pp. 3-12, 2007.

[17] Z. Bu, "The balassa-samuelson effect: a literature review," Shanghai Finance, vol. 5, pp. 36-42, 2015.

[18] S. Hylleberg, R. F. Engle, C. W. J. Granger, and B. S. Yoo, "Seasonal integration and co-integration," North-Holland, vol. 44, no. 1-2, 1990.

[19] J. B. Joseph and A. J. Miron, "Seasonal unit roots in aggregate U.S. data," North-Holland, vol. 55, no. 1-2, 1993.

[20] Z. Su and Y. Lu, "The real exchange rate of RMB and the changes of China's import and export trade structure (1997 2007) - dynamic analysis based on various models," Journal of Quantitative Economics and Technical Economics, vol. 27, no. 5, pp. 3-128, 2010. 